\title{
The Effect of First Trimester Smear Results on Pregnancy and Neonatal Outcomes in a Turkish Population
}

\section{Birinci Trimester Smear Sonuçlarının Gebelik ve Yenidoğan Sonuçlarına Etkisi}

\section{(D) Fatma Ketenci Gencer¹, (D) Semra Yüksel2, (D) Serkan Kumbasar¹, (D Özlem Sögüüt}

${ }^{1}$ University of Health Sciences Turkey, İstanbul Gaziosmanpaşa Training and Research Hospital, Clinic of Obstetrics and Gynecology, İstanbul, Turkey

2University of Health Sciences Turkey, Başakşehir Çam and Sakura City Hospital, Clinic of Obstetrics and Gynecology, İstanbul, Turkey

\section{Abstract}

Objective: We aimed to investigate the relationship between neonatal and pregnancy outcomes and cervicovaginal smear-determined reactive cellular changes and/or inflammation revealing an infectious agent in the first trimester of pregnant patients.

Method: A total of 153 pregnant women, who were in their first trimester period, were enrolled to the study. Records related to the pregnancy and neonates were identified and further analyzed.

Results: In terms of smear results, of 152 patients, 54 (35.5\%) were reported as normal while $96(63.2 \%)$ had reactive cellular changes and/or inflammation and $2(1.3 \%)$ had atypical squamous cells of undetermined significance. In 117 patients (76.4\%), no infectious agent was observed while 22 patients (14.5\%) had fungus (candida), 8 had protozoon (trichomonas vaginalis), and 5 (3.3\%) had bacterial vaginosis. There was no statistically significant difference observed for average pregnancy weeks, baby's birth weight, preterm birth and neonatal intensive care need between patients with reactive cellular changes and/ or inflammation and those with normal smear results $(p=0.72, p=26$, $\mathrm{p}=0.44, \mathrm{p}=0.52$ ).

Conclusion: We found no association between inflammation or reactive cellular changes of smear results in the first trimester of pregnancy and adverse pregnancy or neonatal outcomes as being first research in our country.

Keywords: Neonatal outcome, pregnancy, smear, preterm birth, vaginal infections

\section{Öz}

Amaç: Çalışmamızda gebeliğin ilk trimesterinde başvuran gebe kadınların servikovajinal smear sonuçlarından elde edilen ve enfeksiyöz bir ajanın göstergesi olan reaktif selüler hücre ve enflamasyon bulgularının, gebelik ve neonatal sonuçlar üzerindeki etkisini araştırmayı amaçladık.

Yöntem: Gebeliğinin ilk trimesterinde olan 152 gebe kadın çalışmaya dahil edildi. Gebelik ve yenidoğan sonuçları kaydedilerek analiz edildi.

Bulgular: Gebeliğinin ilk trimesterinde olan 152 gebe kadının smear sonuçlarına bakıldığında 54'ünün $(\% 35,5)$ sonucu normal, 96'sının $(\% 63,2)$ sonucu reaktif selüler hücre ve/veya enflamasyon ve 2'sinin $(\% 1,3)$ sonucunun ise ASCUS (önemi belirlenememiş atipik skuamöz hücreler) olduğu görüldü. Yüz on yedi hastada $(\% 76,4)$ enfeksiyon ajanına rastlanmazken, 22 hastada $(\% 14,5)$ mantar (kandida), 8 hastada protozoon (trichomonas vaginalis), 5 hastada ise $(\% 3,3)$ bakteriyel vajinozis tespit edildi. Smear sonucu reaktif selüler hücre ve/veya enflamasyon ya da normal çıkanlar arasında ortalama gebelik haftası, bebek doğum kilosu, preterm doğum ve neonatal yoğun bakım ihtiyacı bakımından istatistiksel olarak anlamlı bir fark tespit edilemedi $(p=0,72, p=26, p=0,44, p=0,52)$.

Sonuç: illk trimesterde olan gebelerde, smear sonucunun reaktif selüler hücre ve/veya enflamasyon çıkması ile kötü gebelik ve yenidoğan sonuçları arasında anlamlı bir ilişki tespit edilememiştir ve bu çalışma ülkemizde bu konuyu araştıran ilk çalışmadır.

Anahtar kelimeler: Gebelik, neonatal sonuç, preterm doğum, smear, vajinal enfeksiyonlar

Address for Correspondence: Fatma Ketenci Gencer, University of Health Sciences Turkey, İstanbul Gaziosmanpaşa Training and Research Hospital, Clinic of Obstetrics and Gynecology, İstanbul, Turkey

E-mail: fathma_k@hotmail.com ORCID: orcid.org/0000-0002-6076-2563 Received: 13.06.2021 Accepted: 02.11.2021

Cite this article as: Ketenci Gencer F, Yüksel S, Kumbasar S, Söğüt Ö. The Effect of First Trimester Smear Results on Pregnancy and Neonatal Outcomes in a Turkish Population. Bagcilar Med Bull 2021;6(4):376-381

๑C Copyright 2021 by the Health Sciences University Turkey, Bagcilar Training and Research Hospital Bagcilar Medical Bulletin published by Galenos Publishing House. 


\section{Introduction}

Pap smear provides us information about epithelial abnormalities as well as about some vaginal infections. In determining bacterial vaginosis (BV), Pap smear, and microbiological tests have a sensitivity of $43.1 \%$ and $77.8 \%$ and a specificity of $93.6 \%$ and $97.7 \%$, respectively. In that case, despite not being as sensitive as microbiological tests, they are considered enough for the diagnosis of a BV due to its high specificity (1). BV is a common vaginal infection in pregnancy having a prevalence rate of 7-30\% and instead of lactobacillus, there are increased number of Gardnerella vaginalis, Prevotella bacteroides, Mycoplasma hominis, and Mobiluncus (2). Many doctors treat symptomatic BV due to its known association with preterm birth, miscarriage, postpartum endometritis, and lower birth weight. In addition, it is recommended to scan for asymptomatic BV in pregnancy (3). If there is a vaginal infection in pregnant woman originated from aerobic bacteria, it should be treated to improve perinatal results (4). In some publications, authors have reported an association between human papilloma virus (HPV) infection and BV and concluded that HPV-high risk (HPVHR) may be present in case of BV presence (5).

In terms of candidal infections, during a Pap smear evaluation, candidal mycelium and conidium may show a specificity of $99.83 \%$ and $99.62 \%$ and a sensitivity of $92.18 \%$ and $94.53 \%$, respectively (6). Additionally, vaginal candidiasis is observed with a rate of $31.4 \%$ among pregnant women, while its rate is $19.9 \%$ among nonpregnant women. Asymptomatic candidiasis is observed with a rate of $45.6 \%$ among pregnant women, while its rate is $16 \%$ among non-pregnant women. The negative effect of vaginal candidal colonization on perinatal results is not as clear as BV and the efficiency of scanning in pregnancy should be researched (7).

In communities not having got accustomed to periodical control visit, like in our country, visiting doctor for routine control during pregnancy provides a good opportunity to scan neoplastic changes and infectious agents of cervix. Previous studies have showed that one of each 100 cervix cancer patients was pregnant at the time of diagnosis (8). Pap smear test during pregnancy, different results between pregnancy outcomes and cervical inflammation, and HPV infection were reported. The cervical inflammation and HPV infection were associated with negative obstetric outcomes such as preterm birth, preeclampsia, cervical incompetence, and neonatal sepsis. There has been no reported exact association with adverse obstetrical outcomes and newborn outcomes with infectious agents apart from BV in recent reports (9).

In our study, we aimed to investigate the association between the smear results of the women in first trimester and pregnancy or neonatal outcomes.

\section{Materials and Methods}

The study was retrospectively conducted in between March 2018 and May 2019, with the pregnant women in their first trimester visit to University of Health Sciences Turkey, Gaziosmanpaşa Training and Research Hospital, in which smear results and risk factors were evaluated. Ethical approval was obtained from Ethics Committee of University of Health Sciences Turkey, İstanbul Gaziosmanpaşa Training and Research Hospital (no: 91,02.06.2020). Patients' socio-demographical information such as age, smoking status, parity, number of partners, pregnancy week, first sexual activity age, contraception method, and birth styles were recorded. After the required informed consents were obtained, smear results were recorded. One hundred-four pregnant women's hospital records who gave birth in University of Health Sciences Turkey, İstanbul Gaziosmanpaşa Training and Research Hospital, as well as birth and neonatal records of 48 pregnant women who gave birth in another hospital, were obtained by communicating via telephone.

For smear test process in pregnant women, after providing the related information and getting the consent, cervix was visualized in lithotomy position via sterile singleuse speculum and swap sample was taken from cervix with Ayre spatula, then pap-smear samples taken as liquid-based samples were evaluated with Bethesda system in pathology laboratory. Same swap samples were investigated for HPV types, chlamydia, and gonorrhea with real time polymerase chain reaction (PCR) system. Reactive cellular changes were defined as increase of nuclear volume, binucleation, cytoplasmic vacuolization, and polychromasia (10). Intense leukocyte presence in smear was defined as inflammation. Gestational age was determined based on last mensuration dates of patients or based on initial ultrasound measurements if measurements were not conforming with the last mensuration date. Gestational week was recorded in the time of smear test and all of them were less than 14 weeks of gestation. Gestational week of birth was recorded along with birth weight. The babies whose cardiac activities stopped before 20 weeks were defined as miscarriage. 


\section{Statistical Analysis}

Data analysis was done with SPSS $23^{\text {th }}$ version (IBM Corp, Armork, USA). Variables were stated as average \pm standard deviation or median (minimum-maximum). Parametric variables' conformity with normal distribution was evaluated with the Kolmogrov-Smirnov test. In comparison of the variables, the Student-t test or Mann-Whitney U test was used. In comparison of nominal data, the chi-square test was used. $\mathrm{p}<0.05$ value was accepted as statistically significant.

\section{Results}

One hundred-fifty three pregnant women between 18 and 41 years old visited for first trimester control and performed vaginal smear for presence of infectious agents during the study period were included into the study. One patient was excluded due to that her newborn data were not accessible. The study was conducted with 152 pregnant women and newborn results. Patients' socio-demographic data are shown in Table 1. Age range was between 18 and 41 years and the average age was $28 \pm 5.9$ years in our study. The average pregnancy week was 11 weeks. In terms of smear results, among 152 patients, 54 (35.5\%) were reported as normal, while $96(63.2 \%)$ had reactive cellular changes and/or inflammation, and 2 (1.3\%) had atypical squamous cells of undetermined significance (ASCUS). Comparisons were performed between the groups having normal and inflammation and/or reactive cellular results. Considering infectious agent findings obtained from smear results of the population, 117 patients $(76.4 \%)$ had no infectious agent while 22 patients (14.5\%) had fungus (candida), 8 had protozoon (trichomonas vaginalis), and 5 (3.3\%) had BV (Table 2).

After excluding 2 patients with ASCUS, demographical data of remained patients were compared according to the groups having normal smear result and having reactive cellular changes and/or inflammation and results were summarized in Table 3. In terms of the patients' age, smoking status, pregnancy, parity and average pregnancy weeks, there were no difference among the groups. In patients having inflammation in smear result, pelvic inflammatory disease history was meaningfully higher, and first coitus age was also younger [ $(\mathrm{p}=0.03),(\mathrm{p}=0.03)]$ (Table 3). Chlamydia and gonorrhea tests in all patients were resulted as negative. In terms of HPV, 2 pregnant women, having ASCUS results, had negative HPV results. Among the remained 150 patients, in the group having 54 pregnant women with normal smear results, 2 patients
Table 1. Demographic characteristics of the patients

Total number of the patients: 152

\begin{tabular}{ll} 
Age & $28 \pm 5.9(18-44)$ \\
Gravida & $2.5(1-8)$ \\
Parity & $1(0-3)$ \\
Gestational week & $11(5-13)$ \\
Smear result & \\
Normal & $54(35.5 \%)$ \\
Reactive cellular & $96(63.2 \%)$ \\
ASCUS & $2(1.3 \%)$ \\
\hline
\end{tabular}

ASCUS: Atypical squamous cells of which significance were not determined

\begin{tabular}{lll} 
Table 2. Infectious agents obtained from the smear results \\
Infectious agent & Number of cases & Percentage \\
Bacterial vaginosis & 5 & $3.3 \%$ \\
Fungal infection (candida) & 22 & $14.5 \%$ \\
Protozoon (trichomonas) & 8 & $5.8 \%$ \\
None & 117 & $76.4 \%$ \\
\hline
\end{tabular}

had HPV 16 positive and 1 patient had HPV HR positive. In the other group including 96 patients reported to have smear results with inflammation or reactive cellular changes, 1 patient had HPV 16 positive and 2 patients had HPV HR positive. No HPV 18 positivity was observed in each group (Table 4).

Considering groups' pregnancy and neonatal outcomes, no statistically significant difference was observed regarding the average pregnancy weeks, baby's birth weight, preterm birth, and neonatal intensive care need (Table 5). One patient having a smear result reported as reactive cellular changes had in-utero-mort-fetus in the $28^{\text {th }}$ week.

\section{Discussion}

In the retrospective study we conducted, no statistically significant difference was observed between the groups having smear results as normal and the ones with inflammation and/or reactive cellular changes in terms of pregnancy and neonatal outcomes. In the group having a smear result with inflammation, first sexual intercourse age was determined earlier and the rate of patients with PID history was higher ( $\mathrm{p}=0.03, \mathrm{p}=0.03$ ). In a retrospective and community-oriented study by Nimrodi et al. (11), pregnancy and neonatal outcomes of pregnant women having HPV infection or inflammation in Pap smear result were compared and the results were discussed in terms of preterm birth, cervical incompetence, and low birth weight. When the group having HPV positivity or 
Table 3. Comparison of the demographic properties of the groups

\begin{tabular}{llll}
$\mathbf{1 5 0}$ patients & $\begin{array}{l}\text { Smear normal } \\
(\mathbf{n = 5 4})\end{array}$ & $\begin{array}{l}\text { Smear inflammation and/or reactive cellular } \\
\text { changes (n=96) }\end{array}$ & $\mathbf{p}$ \\
\hline Age & $26.9 \pm 6.5$ & $28.6 \pm 5.5$ & $0.08^{\mathrm{a}}$ \\
Smoker women & $6(11.1 \%)$ & $14(14.6 \%)$ & $0.54^{\mathrm{d}}$ \\
Gravida & $2(1-6)$ & $3(1-8)$ & $0.99^{\mathrm{b}}$ \\
Parity & $1(0-3)$ & $1(0-1)$ & $0.37^{\mathrm{b}}$ \\
Multipartnerity & $1(1.9 \%)$ & $2(2.1 \%)$ & $0.99^{\mathrm{d}}$ \\
Gestational week & $9.6 \pm 2.6$ & $10.1 \pm 2.5$ & $0.21^{\mathrm{a}}$ \\
First coitus age & $22.4 \pm 4.5$ & $20.6 \pm 3.8$ & $0.03^{\mathrm{a}}$ \\
History of cesarean section & $8(14.8 \%)$ & $26(27.1 \%)$ & $0.08^{\mathrm{c}}$ \\
History of pelvic inflammatory disease & $1(1.9 \%)$ & $12(12.5 \%)$ & $0.03^{\mathrm{d}}$ \\
Intrauterine device usage & $5(9.3 \%)$ & $10(10.4 \%)$ & $0.82^{\mathrm{c}}$
\end{tabular}

a Student's t-test, b Mann-Whitney $U$ test, c chi-square test, d Fisher's exact test

Table 4. HPV types of the patients

$\begin{array}{lll}\text { Smear result } & \text { Normal } & \text { Inflammation and/or reactive cellular changes } \\ \text { HPV negative } & 51(94.4 \%) & 93(96.9 \%) \\ \text { HPV } 16 \text { positive } & 2(3.7 \%) & 1(1 \%) \\ \text { HPV-HR positive } & 1(1.9 \%) & 2(2.1 \%)\end{array}$

HPV-HR: Human papillomavirus-high risk

Table 5. Comparison of pregnancy outcomes of the patients

\section{0 patients}

Term delivery

Preterm delivery

Birth weight (gr)

Neonatal intensive care unit administration (number, \%)

\section{Smear, normal}

$38.4 \pm 2.0$

$7(14 \%)$

$3304 \pm 500$

$9(16.7 \%)$
Inflammation and/or reactive cellular changes

$38.3 \pm 1.8$

7 (8\%)

$3239 \pm 464$

$11(11.5 \%)$ p

$0.72^{\mathrm{a}}$

$0.26^{b}$

$0.44^{a}$

0.51

a Student's t-test, $\mathrm{b}$ chi-square test, one patient who had reactive cellular changes in her smear result was diagnosed with in utero mort fetus in the $28^{\text {th }}$ week of gestation

inflammation in Pap smear was compared with the group having no anomaly, it was concluded that there was no statistically significant difference between obstetric or neonatal outcomes (11). In our study, we observed that HPV positivity was very low, so it was not possible to evaluate risk statistically but we neither determined a meaningful difference in comparison of newborn results of the group having a smear result with inflammation or reactive cellular changes, and the group having a normal smear result. In another community-oriented study by Buchmayer et al. (12), finding of coccobacillus or trichomonas in Pap smear samples taken from pregnant women was evaluated as risky in terms of fetal development, and if this positive result was within 4 weeks prior to the birth, it was associated with 4 times more risk of preterm birth. In our study, trichomonas vaginalis was determined in 8 cases and bacterial agent in 5 cases. Neonatal outcomes of these patients were not negative. In a cohort study by Jacobsson et al. (13), even not being statistically significant, 2 times more preterm delivery was observed in pregnant women having a pap smear result with $\mathrm{BV}$ within first trimester, and also a threefold increase was determined in these patients' postpartum endometriosis frequency. In our study, we investigated Pap smear in pregnant women within first trimester and the percentage of smears with bacterial agent was $3.3 \%$, and there was no negativeness observed in these patients' neonatal outcomes.

In a study by Quinlivan et al. (14) including pregnant women younger than 17 years old, $27 \%$ of the participants had chlamydia positivity and $38 \%$ had abnormal smear findings. It is especially stated that scanning and treating chlamydia is important in terms of reducing newborn febrile morbidity (14). In our study, there was no adolescent pregnant, and all chlamydia results were negative, in this respect we believe that the chlamydia is not a threatening agent for our region. 
In smear samples taken by Helou et al. (15) from pregnant women within 15-20 weeks, BV was determined in $15 \%$ of the patients and it was concluded that this rate was not associated with preterm birth. Pregnant women who are in their first trimester $\left(<14^{\text {th }}\right.$ weeks of gestation) were included in our study and BV frequency was $3.3 \%$. The difference in BV rate may be resulted from the patient group being within different gestational weeks but still, the preterm delivery was not associated with BV in both studies. In a study by Svare et al. (16), including pregnant women within second trimester, BV was determined in $16 \%$ of cervical smear samples and it was concluded that this condition constituted an independent risk for lower birth weight, preterm birth and chorioamnionitis. The study of Svare et al. (16) was conducted on pregnant women before 20 weeks within second trimester, in this respect the obtained results might be associated with the selected patient group.

In a study by Smith et al. (17), HPV positivity rate in pregnant women within first trimester was determined as $0.8 \%$. In our study, this rate was determined as $1.3 \%$ and, also 2 patients having a smear test with ASCUS had a negative HPV result. In the remaining patients, no statistically significant difference was determined between the group having a normal smear result and the group having a smear result with inflammation or reactive cellular changes in terms of HPV positivity (17).

There are few studies related to this condition in our country. İvit et al. (18) determined BV in $16 \%$ of patients, candida in $10 \%$ and trichomonas in 5\%, and this study only reveals the frequency of infectious agents in first trimester. The most frequent vaginal infection in our study was fungus (candida) with a rate of $14.5 \%$. BV rate was $3.3 \%$, while trichomonas rate was $5.8 \%$. Apart from BV frequency, both studies had similar results. In our country, cervical smear studies on pregnant women are rather related to the reliability of smear on pregnant women and almost all concluded that it is a good scan during pregnancy (19-21).

\section{Study Limitations}

During the study, we had some limitations. The most important limitations were the sample size and the low frequency of infectious agents detected in Pap smear; therefore, statistical analysis was not too strong for the infected cases.

\section{Conclusion}

We found no association between inflammation and/or reactive cellular changes of smear results in the first trimester of pregnancy and adverse pregnancy or neonatal outcomes. This is the first study investigating the relationship between first trimester smear results on pregnancy and neonatal outcomes in our country. For revealing this relation better, studies having a broader sample size are needed.

\section{Ethics}

Ethics Committee Approval: The ethical approval was obtained from Ethics Committee of University of Health Sciences Turkey, İstanbul Gaziosmanpaşa Training and Research Hospital (no: 91, 02.06.2020).

Informed Consent: Informed consent was obtained from all the patients.

Peer-review: Externally peer-reviewed.

\section{Authorship Contributions}

Concept: F.K.G., S.Y., S.K., Design: F.K.G., S.Y., S.K., Data Collection or Processing: F.K.G., S.Y., Ö.S., Statistical Analysis or Interpretation: S.Y., Drafting Manuscript: F.K.G., Critical Revision of Manuscript: S.Y., S.K., Final Approval and Accountability: F.K.G., S.Y., S.K., Ö.S., Technical or Material Support: F.K.G., S.K., Ö.S., Supervision: S.Y., S.K.

Conflict of Interest: No conflict of interest was declared by the authors.

Financial Disclosure: The authors declared that this study received no financial support.

\section{References}

1. Tokyol C, Aktepe OC, Cevrioğlu AS, Altindiş M, Dilek HF. Bacterial vaginosis: comparison of pap smear and microbiological test results. Modern Pathol 2004;17(7):857-860.

2. Haahr T, Ersbøll AS, Karlsen MA, Svare J, Sneider K, Hee L, et al. Treatment of bacterial vaginosis in pregnancy in order to reduce the risk of spontaneous preterm delivery - a clinical recommendation. Acta Obstet Gynecol Scand 2016;95(8):850-860.

3. Peterek J. Znaczenie badania ekosystemu pochwy u ciezarnych w pierwszym trymestrze ciazy [Importance of the vaginal ecosystem examination in the first trimester of pregnancy]. Ginekol Pol 2003;74(12):1526-1530.(Polish)

4. Han C, Wu W, Fan A, Wang Y, Zhang H, Chu Z, et al. Diagnostic and therapeuticadvancements for aerobicvaginitis. Arch Gynecol Obstet 2015;291(2):251-257

5. Kero K, Rautava J, Syrjänen K, Grenman S, Syrjänen S. Association of asymptomatic bacterial vaginosis with persistence of female genital human papillomavirus infection. Eur J Clin Microbiol Infect Dis 2017;36(11):2215-2219.

6. Momenzadeh M, Sehhati M, Mehri Dehnavi A, Talebi A, Rabbani H. Automatic diagnosis of vulvovaginal candidiasis from pap smear images. J Microsc 2017;267(3):299-308.

7. Holzer I, Farr A, Tan Y, Deutschmann C, Leser C, Singer CF. The colonizationwith Candida species is moreharmful 
in the secondtrimester of pregnancy. Arch Gynecol Obstet 2017;295(4):891-895.

8. Gungorduk K, Sahbaz A, Ozdemir A, Gokcu M, Sancı M, Kose MF. Management of cervical cancer during pregnancy. J Obstet Gynaecol 2016;36(3):366-371.

9. Matei A, Saccone G, Vogel JP, Armson AB. Primary and secondary prevention of preterm birth: a review of systematic reviews and ongoing randomized controlled trials. Eur J Obstet Gynecol Reprod Biol 2019;236:224-239.

10. Marshall LM, Cason Z, Cabaniss DE, Lemos LB, Benghuzzi HA. Reactive cell change in cervicovaginal smears Biomed Sci Instrum 1997;33:298-304.

11. Nimrodi M, Kleitman V, Wainstock T, Gemer O, Meirovitz M, Maymon E, et al. The association between cervicalinflammation and histologic evidence of HPV in PAP smears and adverse pregnancy outcome in low risk population. Eur J Obstet Gynecol Reprod Biol 2018;225:160-165.

12. Buchmayer S, Sparén P, Cnattingius S. Signs of infection in Pap smears and risk of adverse pregnancy outcome. Paediatr Perinat Epidemiol 2003;17(4):340-346.

13. Jacobsson B, Pernevi P, Chidekel L, Jörgen Platz-Christensen J. Bacterial vaginosis in early pregnancy may predispose for preterm birth and postpartum endometritis. Acta Obstet Gynecol Scand 2002;81(11):1006-1010.

14. Quinlivan JA, Petersen RW, Gurrin LC. High prevalence of chlamydia and Pap-smear abnormalities in pregnant adolescents warrants routine screening. Aust N Z J Obstet Gynaecol 1998;38(3):254-257.
15. Helou J, Keness Y, Shalev E. [Association of bacterial vaginosis in pregnancy with preterm delivery]. Harefuah 1996;131(3-4):83-5, 144,143. (Hebrew)

16. Svare JA, Schmidt H, Hansen BB, Lose G. Bacterial vaginosis in a cohort of Danish pregnant women: prevalence and relationship with preterm delivery, low birthweight and perinatal infections. BJOG 2006;113(12):1419-1425.

17. Smith EM, Parker MA, Rubenstein LM, Haugen TH, Hamsikova E, Turek LP. Evidence for vertical transmission of HPV from mothers to infants. Infect Dis Obstet Gynecol 2010;2010:326369.

18. İvit H, Köksal A, Cukurova K, Yetimalar H, Keklik A, Yıldız A, İnceoğlu $M$. The incidence of the vaginalinfections in early pregnancy. Tepecik Eğit Hast Derg 2008;18(3):109-111.

19. Yaltı S, Altıntepe G, Dayıcıoğlu V. Cervical screening in pregnant patients. Zeynep Kamil Tıp Bülteni 2002;34(1):7-11.

20. Abalı R, Bozkurt HS, Aksu M, Koçyıldız Z, Dursun N. The evaluation of cervicovaginal cytological changes during pregnancy. Maltelepe Tıp Dergisi 2009;1(1):38-46.

21. Aktün LH, Aykanat Y, Gökdağlı Sağır F. Are cervicovaginal smear tests reliable during pregnancy? Medeniyet Med J 201732(2):111114. 